\title{
The role of maternal rumination, maternal perception of disease severity, executive functions, and surgical-related factors in predicting psychological outcomes in children with congenital heart disease
}

\author{
Fateme Younesi $^{1}$, Hamidreza Hassanabadi ${ }^{*}$ (D), Robabe Noury Ghasemabadi ${ }^{3}$, \\ Alireza Moradi ${ }^{4}$, Kourosh Vahidshahi ${ }^{5}$
}

\begin{abstract}
1. PhD Candidate of Health Psychology, Kharazmi University, Tehran, Iran
2. Assistant Professor of Educational Psychology, Department of Educational Psychology, Kharazmi University, Tehran, Iran

3. Associate Professor of Clinical Psychology, Department of Clinical Psychology, Kharazmi University, Tehran, Iran

4. Professor of Clinical Psychology, Department of Clinical Psychology, Kharazmi University, Tehran, Iran

5. Associate Professor of Pediatric Cardiology, Department of Pediatric Cardiology, Shahid Beheshti University of Medical Sciences,

Tehran, Iran
\end{abstract}

Recieved: 25 Dec. 2019

Revised: 16 Jun. 2020

Accepted: 22 Jun. 2020

Keywords

Children with congenital heart disease

Psychological outcomes

Maternal rumination

Problem solving

Corresponding author

Hamidreza Hassanabadi, Assistant Professor of Educational Psychology, Department of Educational Psychology, Kharazmi University: No.43. South Mofatteh Ave. Tehran, Iran

Email: Dr-hassanabadi@khu.ac.ir

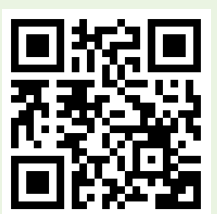

\section{Abstract}

Introduction: Congenital heart disease is the most common fetal disease and the second leading cause of death in infants and children. This study aimed to identify the key psychological and biological factors affecting the psychological outcomes of these children.

Methods: This study was correlational. The study's participants included all children aged 8-12 years with congenital heart disease of cyanosis type and their mothers who referred to Shahid Rajaee Heart Hospital. A random sampling method was considered including 338 children and their parents. The Shallice (1982) Tower of London test, performed on children, and the Nolen-Hoeksema (1999) Rumination Response Scale and the Rutter (1967) Behavioral Scale, were answered by mothers, were used to collect data. The mothers of these children also answered two questions about the mother's perception of the severity of the illness and the severity of the child's physical limitations. The disease information was extracted from children's records. Data analysis was performed in SPSS-25 software using the stepwise multiple regression method.

Results: According to the results, maternal rumination, maternal perception, and severity of physical limitation predicted $16 \%$ of the child's anxiety/depression. Mother's rumination and child's problem solving predicted $13 \%$ of the aggression/hyperactivity variable. Rumination and problem solving predicted $10 \%$ of antisocial behavior and $7 \%$ of child social maladaptation. Rumination predicted $8 \%$ of attention deficits and eventually hospitalizations predicted $2 \%$ of problem solving. Among these variables, maternal rumination of depression symptoms had the highest predictive power while the number of hospitalizations had the least predictive power. Conclusion: Psychological factors, especially maternal factors, played a more crucial role in the psychological outcomes of children than the factors related to surgery.

Citation: Younesi F, Hassanabadi H, Noury Ghasemabadi R, Moradi A, Vahidshahi K. The role of maternal rumination, maternal perception of disease severity, executive functions, and surgical-related factors in predicting psychological outcomes in children with congenital heart disease. Advances in Cognitive Sciences. 2020;22(3):1-13. 


\section{نقش نشخوار فكرى مادر، ادراك مادر از شدت بيمارى، حل مساله و عوامل مرتبط با جراحى در بيشبينى بيامدهاى روانشناختى در كودكان مبتلا به بيمارىهاى قلبى مادرزادى}

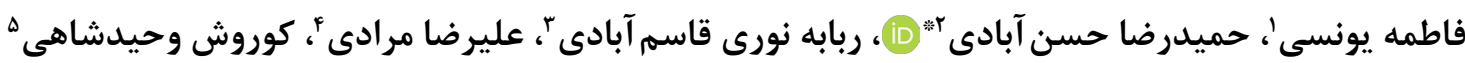

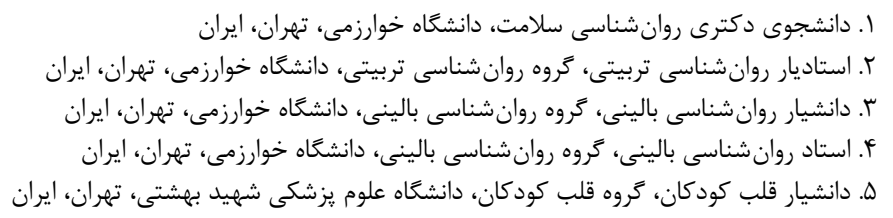

\section{ars}

مقلدمه: بيمارى قلبى مادرزادى شايع ترين بيمارى دوران جنينى و دومين علت مرك در نوزادان و كودكان است. هدف مطالعه حاضر تشخيص عوامل كليدى روانشناختى و زيستى تاثيركذار بر يِيامدهاى روانشناختى ين كودكان بود. روش كار: اين مطالعه از نوع همبستگى بود. جامعه آمارى شامل تمام كودكان ז|-1 سال مبتلا به بيمارى قلبى مادرزادى از نوع سيانوز مراجعه كننده به بيمارستان قلب شهيد رجايى بود. ^بr نفر از كودكان و والدينشان به شيوه نمونه گيرى غير تصادفى و از نوع در دسترس وارد مطالعه شدند. براى كردآورى دادهها از آزمون بج لندن Shallice (IMT) كه روى كودكان اجرا شد و يرسشنامه هاى نشخوار فكرى Nolen-Hoeksema (1999) و فهرست اختلال هاى رفتارى (199V) Rutter و شدت محدوديت فيزيكى كودى ياسخ دادند. اطلاعات مربوط به بيمارى نيز از يروندهاى كودكان استخراج شد. تجزيه و تحليل دادهها در نرمافزار SPSS-25 و با استفاده از روش تحليل ركرسيون خندكانه به شيوه كام به كام انجام شد. يافته ها: نشخوار فكرى مادر، ادراى مادر و شدت محدوديت فيزيكى در مجموع 1 درصد از اضطراب/افسردكى كودى را پيشبينى كردند. نشخوار فكرى مادر و حل مسئله سا درصد از متغير يرخاشكرى/بيشفعالى را بيشبينى كردند. نشخوار فكرى و حل مسئله •ا درصد از رفتار ضد اجتماعى و ل درصد از ناسازكارى هاى اجتماعى كودى را ريش بينى كردند. نشخوار فكرى \ درصد از نقص توجه و در نهايت دفعات بسترى ك درصد از حل مسئله را يیشبينى كردند. از بين اين متغيرها، نشخوار فكرى مادر بيشترين قدرت پِيشبينى و تعداد دفعات بسترى در بيمارستان كمترين قدرت پيشبينى را داشتند. نتيجه كيرى: عوامل روانشناختى به ويثه عوامل مرتبط با مادر، نسبت به عوامل مرتبط با جراحى نقش مههمترى در بيامدهاى روانشناختى كودكان ايفا كردند.
}

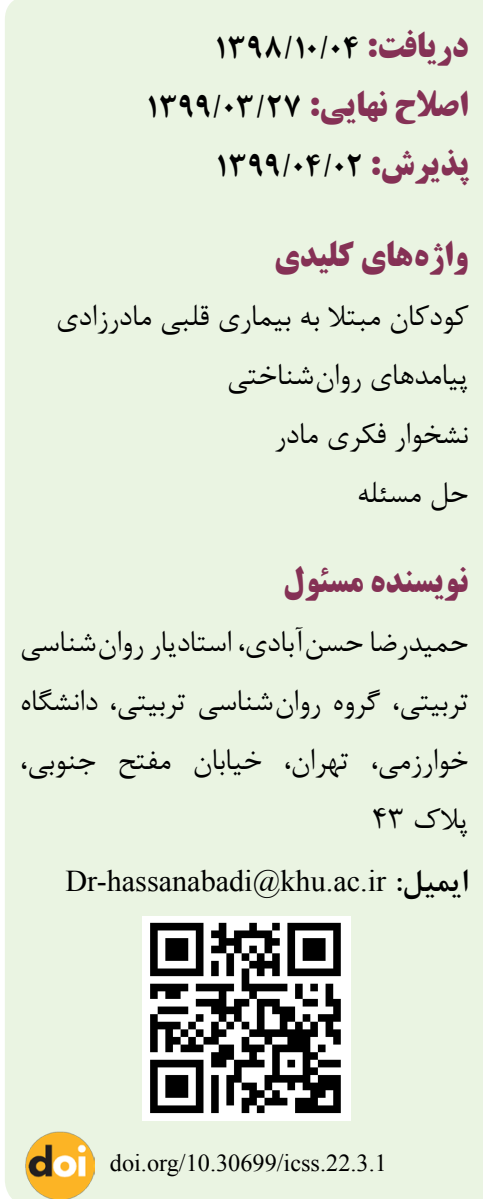

مقدمه

مىشوند. شكل شديد اين بيمارى به انواعى كفته مى شود كه در همان

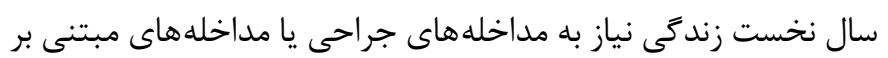
كاتتريزاسيون دارند و يا منجر به مرى نوزاد مىشوند (1). در جندين دهه گذشته با رشد روش هاى جراحى جديد به طور قابل توجهى ميزان مرى و مير در كودكان و نوجوانان CHD ييجيده كاهش يافته است.
بيمارى هاى قلبى مادرزادى (Congenita Heart Disease (CHD) شايعترين بيمارى دوران جنينى است و از هر . ․ . إكودكى كه زنده به دنيا مى آيند تقريبا • ا نوزاد مبتلا به انواع بيمارى هاى قلبى مادرزادى هستند. طيف گستردهاى از شدت اين بيمارى اعم از نقص هاى جزئى تا ناهنجارى هاى بسيار پيجيده كه اثرات هميشكى بر كودى دارند مشاهده 
دور مىزنند. اين افكار به طريق غير ارادى، وارد آكاهى مىشوند و توجه را از موضوعات مورد نظر و اهداف فعلى منحرف مى سازند (r). (1).

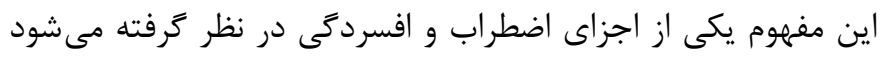

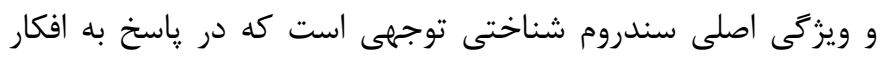

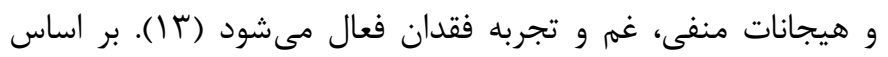

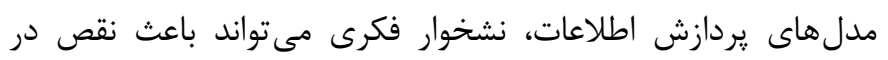

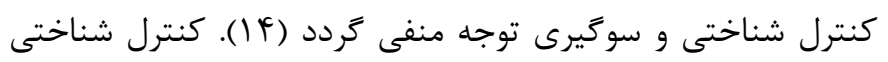
به مجموعهاى از فرايندها اشاره دارد كه شناخت و رفتار انعطاف يذير لتير را لحظه به لحظه براى رسيدن به اهداف تسهيل مى كند. اين مفهوم با

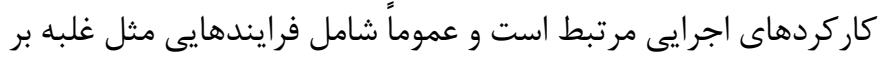
ياسخهاى قدرتمند از ييش تعيين شده و بازدارى اطلاعات غير مرتبط، جابجايى تمركز و بهروزرسانى حافظه كارى است (هال)، اين مشكلات

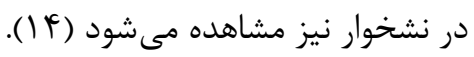

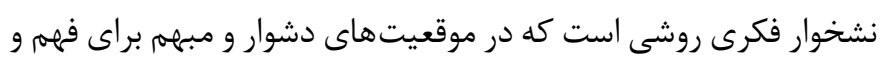

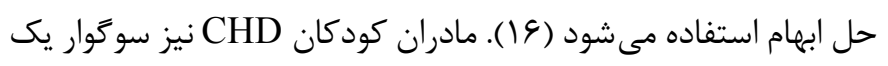

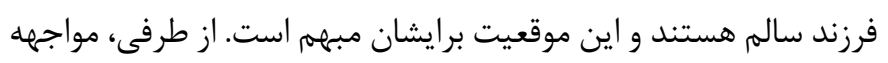
با مراحل مختلف تشخيص و درمان و جراحى هاى متعدد نيز تجارب دشوار و آسيبزايى هستند كه ممكن است شرايط نشخوارى را براى والدين اين كودكان فراهم كنند. توجه مادران نشخوار كننده در رسيدن به اهداف مادرى خود نسبت به كودكان CHD يكيار خه نبوده و قادر به

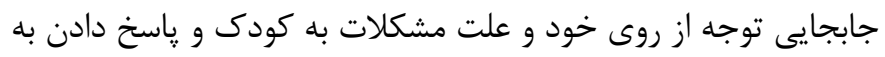

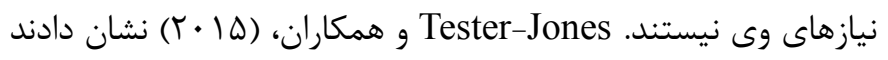

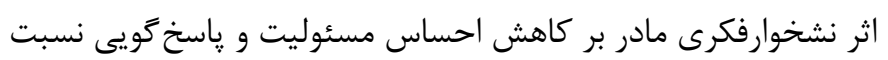
به نيازهاى كودى وقتى كه كودكان هيجانات منفى شديدى نشان

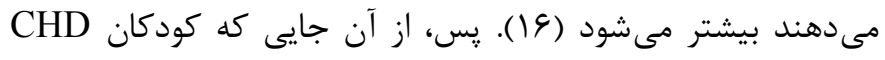

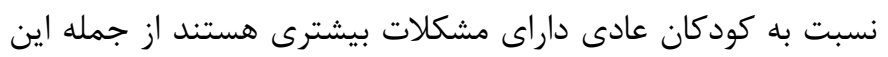

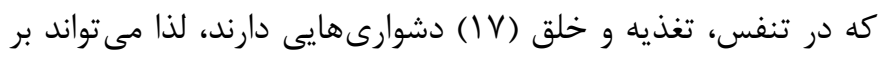

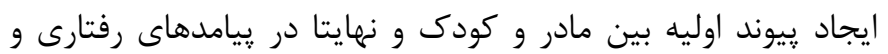
هيجانى اين كودكان اختلال ايجاد كند.

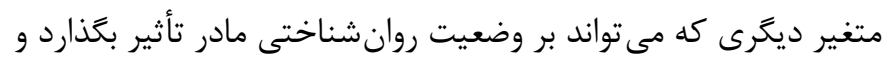

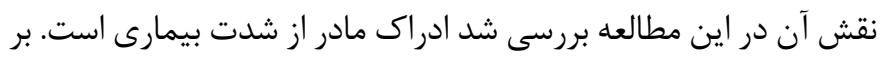

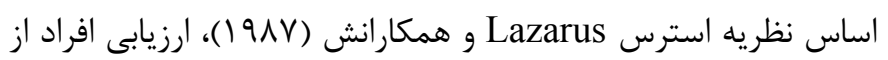

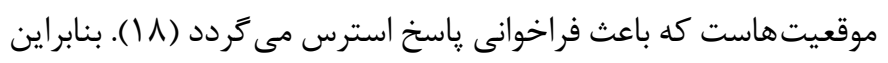

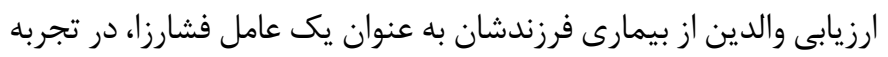

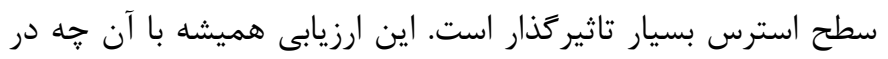
واقعيت وجود دارد همخوان نيست بنابراين ممكن است ارزيابى مادر از شدت بيمارى با شدت واقعى بيمارى ناهمخوان باشد. از طرفى، ادراى

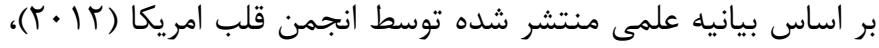

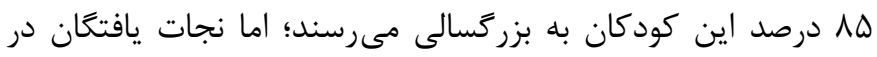
معرض خطر آسيبهاى عصب تحولى (Neurodevelopment (ND)،

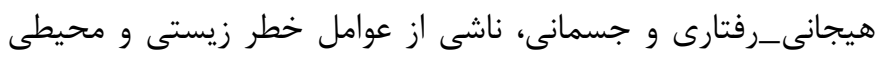

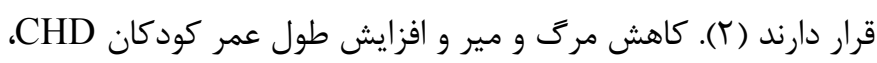
اين بيمارى را در طبقه بيمارىهاى مزمن قرار داده است. بنابراين،

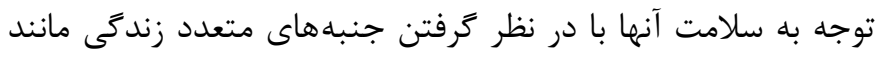

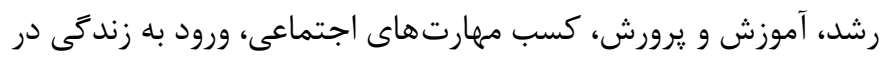

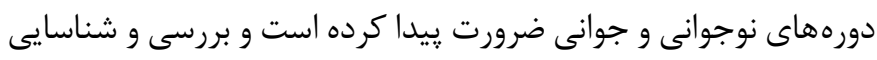
متغيرهاى موثر بر بيامدهاى روانشناختى اين كودكان از اهميت زيادى

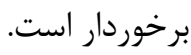
يزوهشها عوامل خطر آفرين زيستى و روانشناختى متعددى ذكر استر كردهاند كه در ييامدهاى جسمى و روانشناختى كودكان CHD تاثير

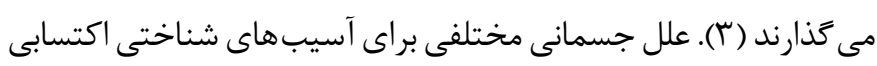

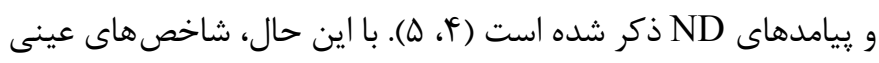

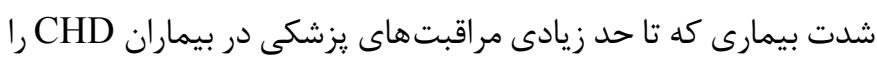

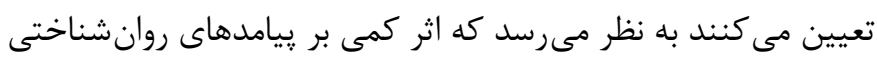

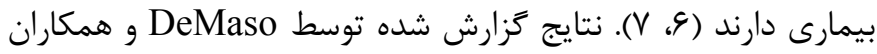

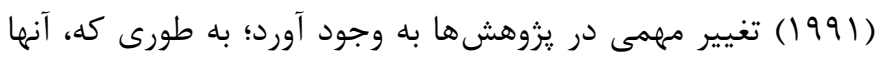

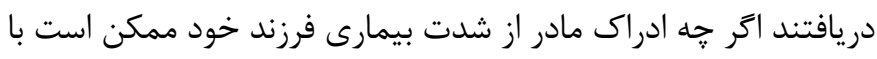

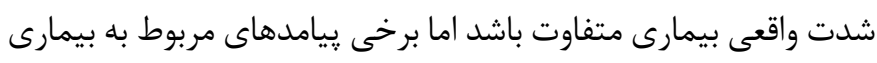

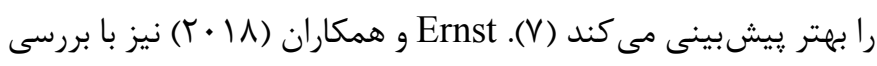

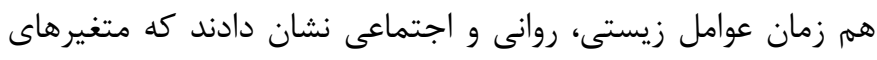

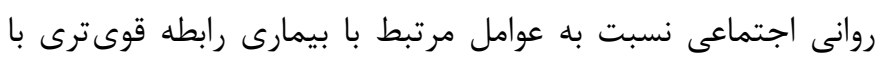
كيفيت زندگى بيماران دارند (^). (1).

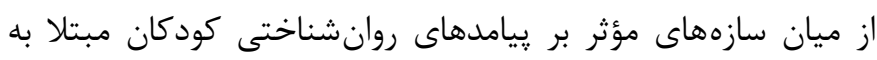
CHD

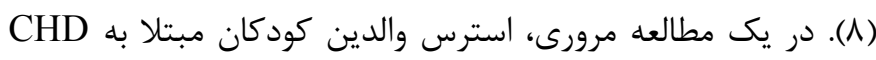

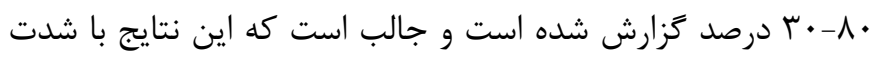

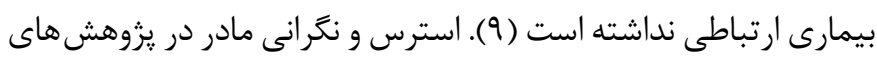

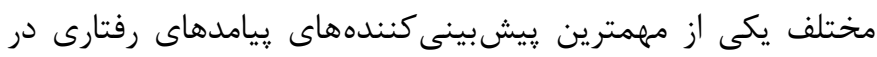

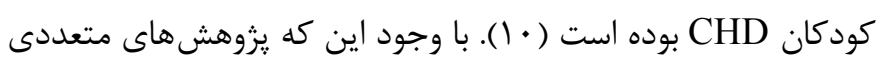

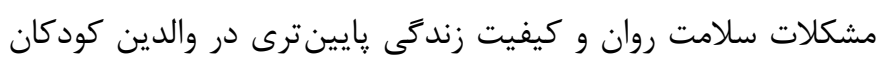

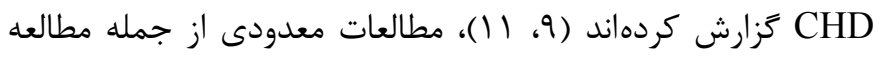
Schmidt روانشناختى كودكان را بررسى كردهاند (1). نشخوار فكرى به عنوان

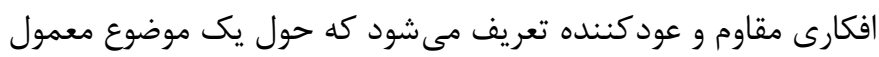


يروهشها نشان دادند كه طولانى شدن مدت زمان توقف گردش خون حين عمل مى تواند منجر به ايجاد مشكلات كفتارى در كودكان مبتلا به

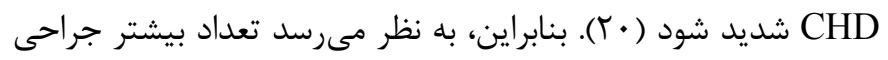
جون همراه با مدت زمان بيشتر تحت يمٍ قرار گرفتن نيز هست، منجر به آسيبهاى روانشناختى بيشترى گردد. همجنين، تعداد جراحى ها و و بسترى شدن هاى مكرر مى تواند به واسطه جدايى از خانواده به طور بالقوه براى كودك و حتى خانوادهاش فشارزا باشد ( آY)، در يك مطالعه تعداد جراحى ها ييشبينى كننده اضطراب والدين نيز بود (YT). افزون بر اين، بسترىهاى طولانى مدت و شدت محدوديت هاى فيزيكى مى تواند به شيوه هاى گوناگون بر ييامدهاى روانشناختى اين كودكان تأثير بكذارند. بسترىهاى متعدد و طولانى مدت در بيمارستانها مىتواند بر رشد شناختى كودكان در بلند مدت نيز تاثير بحذارد. بر اساس نظريه Piaget ( PVV) رشد شناختى كودى در مرحله حسى_حركتى بستگى به ميزان تحرك و جستجوگرى كودى نويا دارد (TM). محدوديتهاى فيزيكى مرتبط با نقصهاى عصبى تكاملى و استقامت يايين نيز اين كودكان را معرض كاهش ظرفيت بازى و فعاليتهاى فيزيكى كه مهارت هاى اجتماعى و سازگًارى روانشناختى را بالا مىبرد، قرار مى دهد (·). تحمل يايين و ناتوانى در ورزش حدود يك سوم بيماران CHD از نوع ساده و ييجيده را تحت تاثير قرار مى دهد. بسيارى از آنها كاهش جذب اوج اكسيرن، كاهش اشباع اكسيزرن، كاهش آستانه گردش بى هوازى و گِاسخ مختل زمانى در طول

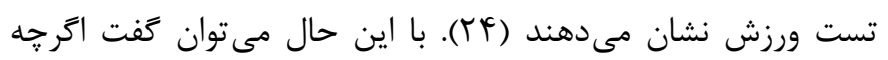
برخى از كودكان CHD شديد از انجام ورزشهاى سنگين كه نياز به حداكثر ظرفيت ورزشى دارد منع مىشوند اما اغلب آنها محدوديتى در ورزش هاى سبكتر ندارند و اغلب ورزش ها و فعاليتهاى روزانه نيز نياز به حداكثر فعاليت ورزشى ندارند. با اين وجود، برخى والدين در موارد غير ضرورى فرزند خود را محدود مى كنند كه اين مسئله مى تواند باعث

افسردگى و انزواى اجتماعى كود كان گردد (ها؟). متغير ديخرى كه اثر آن بر ييامدهاى روانشناختى نمونه حاضر بررسى إنى شد، حل مسئله بود. حل مسئله يكى از كاركردهاى اجرايى محسوب مىشود كه داراى ابعاد شناختى و هيجانى است. اخيرا كاركردهاى اجرايى به كاركردهاى گرم و سرد تقسيم شدهاند كه كاركردهاى اجرايى سرد به عنوان مهارتهاى هدفمند و آينده محور مانند برنامهريزى، مهار، انعطاف يذيرى، حافظه كارى و نظارت كه در شرايط نسبتا مجزا، غير هيجانى و آزمون تحليلى نمود ميىيابند، تعريف شدهاند. در مقابل، كاركردهاى اجرايى گرم، فرايندهاى شناختى هدفمند و آينده محور هستند كه از زمينههايى بيرون مى آيند كه هيجان، انخيزه، و تنش بين
مادر از شدت بيمارى مىتواند در جُخونكى ايجاد محدوديتها براى فرزندشان و نيز بر رفتار آنها تاثير گذار باشد. بر اساس مدل هاى سلامت، از جمله الكوى باور سلامت Becker و همكاران (••191)، باورها و ادراكات افراد پيشبينى كنندههاى رفتار سلامت هستند (1) إ). از آن جايى كه اغلب روان شناسان به خصوص نظريهيردازان روابط موضوعى بر نقش كليدى مادر در تحول كودى تأكيد دارند، گِ بس باور مادر درباره سلامتى كودك مىتواند منجر به رفتارهاى مؤثر بر رشد كودى گردد. بنابر اين، ادراك مادر هم از طريق تأثير گذارى بر اتخاذ رفتارهاى سلامت و هم بر سلامت روان مادر مىتواند بر ييامدهاى روانشناختى كودكان

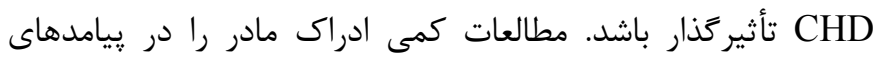
روانشناختى كودكان CHD بررسى كردهاند به طور مثال، يزوهش DeMaso والدينى، استرس والدين و ادراى از شدت بيمارى كودكشان مىشد، روى سازگارى كودكان CHD بررسى كردند. آنها ثابت كردند كه ادراكات مادر در مقايسه با شدت بيمارى بيشبينى كننده قوىترى از سازكارى كودى بود. اين :ززوهش حاكى از تأثير ادراك مادر روى

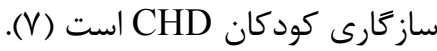
همانطور كه اشاره شد، علاوه بر عوامل روانشناختى و خانوادگى، متغيرهاى زيستى نيز به عنوان عوامل موثر بر ريامدهاى ND و روانشناختى در اين كودكان در نظر گرفته شدند (ب). عوامل زيستى مرتبط با قبل، حين و يس از عمل در يزوهشهاى مختلف بررسى شده

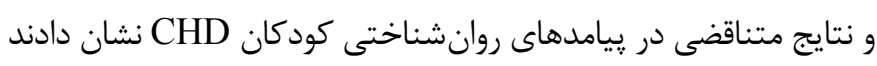

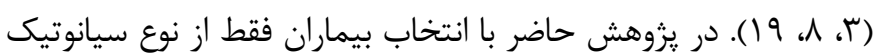
(سيانوز اصطلاحى است كه براى توصيف تغيير رنت يوست يا غشاهاى مخاطى به كبودى در نتيجه اكسيرن رسانى ناكافى به خون به كار مىرود) سعى در كنترل تقريبى عوامل قبل از عمل مانند هييوكسى (شرايطى كه در آن بدن يا ناحيهاى از بدن از ميزان كافى اكسيرن در سطح بافت محروم مىشود) شد. از ميان عوامل مرتبط با جراحى نيز تعداد جراحى هاو تعداد دفعات بسترى و شدت محدوديتهاى فيزيكى به منظور بررسى نقش ييشبينى كننده بر بيامدهاى روانشناختى كودكان

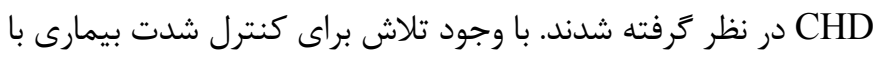
انتخاب صرفا كودكان CHD سيانوتيك در يروهش حاضر، عوامل مرتبط با جراحى مى توانند تا حدودى نشاندهنده يِيجيدگى هاى درمانى در اين طبقه خاص نيز باشد. در طول جراحى عملكرد قلب و ريه توسط مدار و يمٍٍ اكسيزنساز انجام مىشود. بدن به ويزه مغز قدرت تحمل اين وضعيت به مدت طولانى را ندارد و توقف گردش بيش از •r دقيقه ممكن است خطر آسيب دائم مغزى با خود داشته باشد. به طور مثال، 
اختلال حاد روان يزشكى داشتند از نمونه هاى مورد مطالعه خارج شدند و نيز كودكانى كه به علت مراجعه مكرر به بيمارستان ترك تحصيل كرده بودند وارد مطالعه نشدند. مادران داراى حداقل سواد خواندن و نوشتن

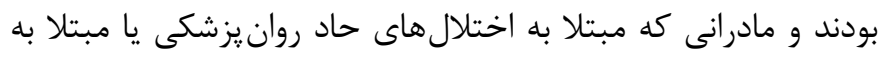

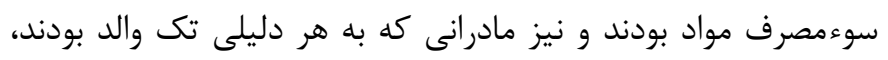

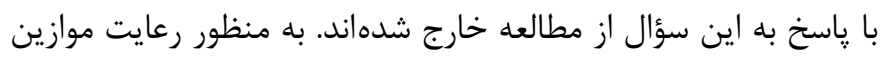

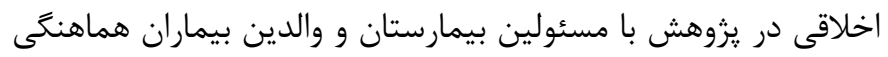
صورت كرفت و رضايت آنها كسب گرديد. همجنين يزوهش حاضر با بان كد IR.RHC.REC.1397.004 در كميته اخلاق بيمارستان قلب و عروق شهيد رجايى مورد بررسى و تصويب قرار كرفت. شيوه اجرا به

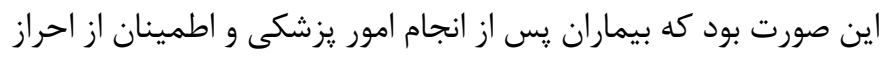

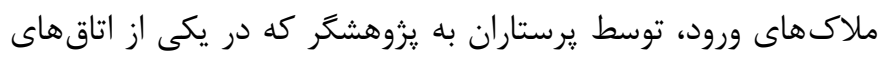

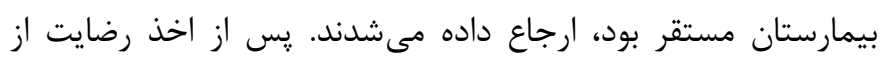

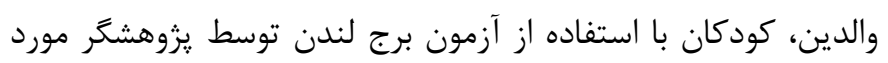

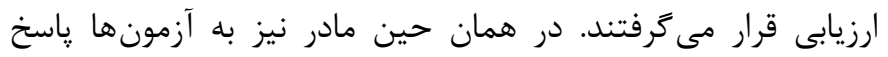

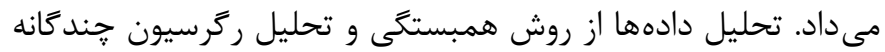
كام به كام با استفاده از نرمافزار SPSS-25 انجام شدام ابزارهاى به كار ترفته در اين مطالعه عبارتند از: مقياس ياسخ نشخوارى: اين مقياس زير مقياسى از يرسشنامه

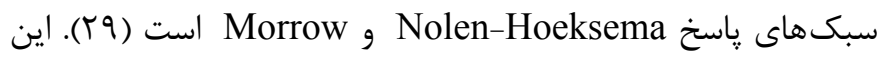

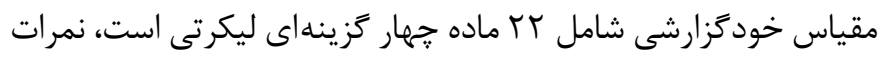

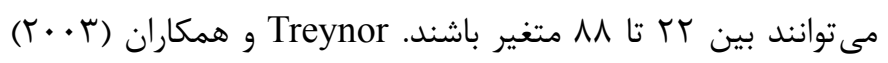

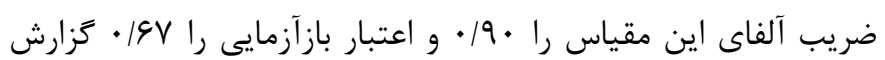

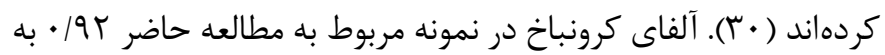

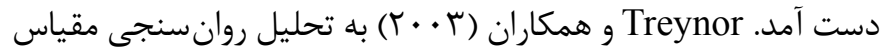
ياسخ نشخوارى يرداختند و از مدل دوعاملى ياسخ هاى نشخوارى حمايت كردند. مؤلفه اول تعمق و مؤلفه دوم درخود فرورفتن ناميده شده است، بقيه سوال ها مرتبط با نشانههاى افسردگى بودند (• بَ). محمدخانى و

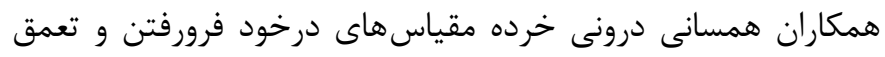

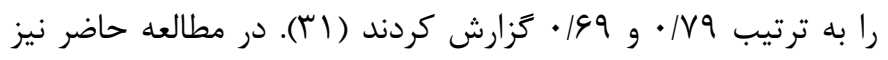

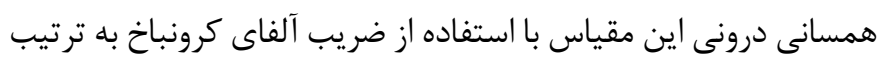

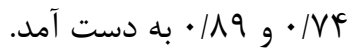
آزمون برج لندن (Tower of London Test): Shallice) ( ( ) ( ) تكليف برج لندن را براى اندازهزيرى برنامهريزى و مهارتهاى حل

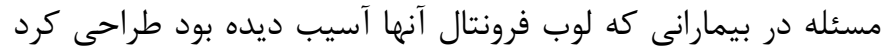

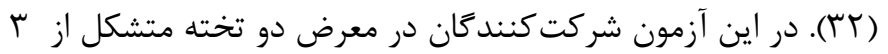

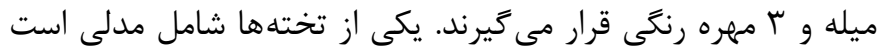

لذت فورى و ياداش بلند مدت ايجاد مى كند (צ؟). حل مسئله هم بخش

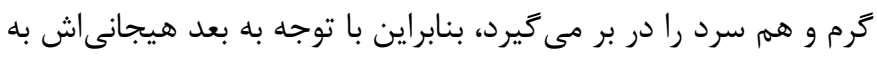

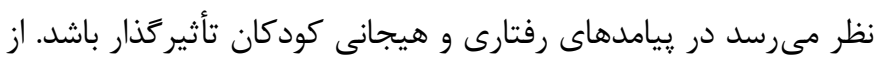

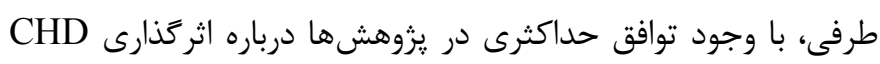

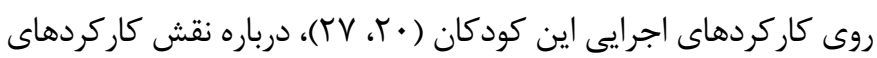

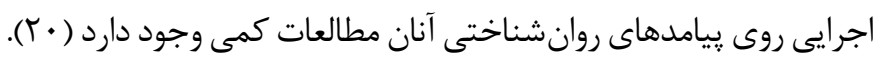
برخى از يزوهشها روى كودكان غير بيمار نيز نتايج متناقضى درباره نقش بنش نقص در كاركردهاى اجرايى بر خطر ابتلا به اختلال هاى روانيزشكى و بردي

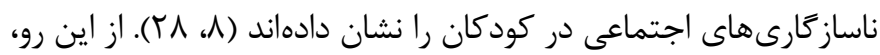
مطالعه حاضر، بر آن شد تا نقش حل مسئله كه به نوعى ييامد بيمارى قلبى مادرزادى نيز محسوب مى شود را به عنوان متغير ييشبينى كننده

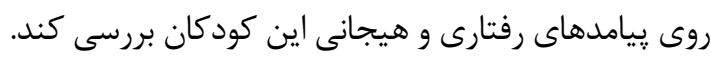

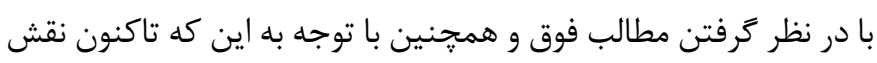

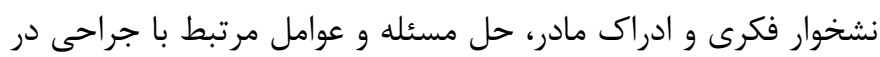
كودكان CHD در جمعيت كودكان CHD ايرانى مورد بررسى قرار نكرفته است، يزوهش حاضر به دنبال بررسى نقش اين متغيرهاى مهمه در تعيين ييامدهاى روانشناختى اين كودكان بود. به علاوه با توجه به نقش يررنگتر مادران ايرانى در زندگى فرزندان خود و همجنين

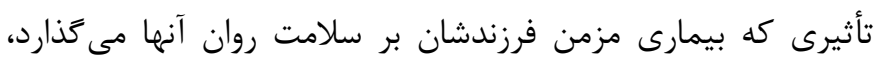

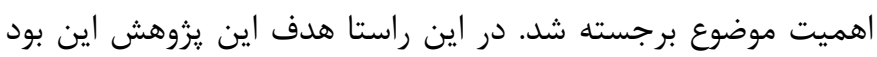

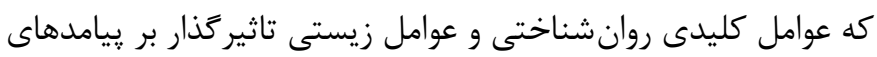
روانشناختى كودكان CHD را شناسايى نمايد.

روش كار

در اين مطالعه از يك طرح همبستخى استفاده شد. جامعه آمارى يروهش شامل تمام كودكان T|-1 سال مبتلا به بيمارى قلبى مادرزادى از نوع

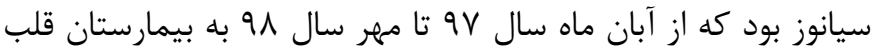
شهيد رجايى شهر تهران مراجعه كرده بودند. شيوه نمونهَيرى غير

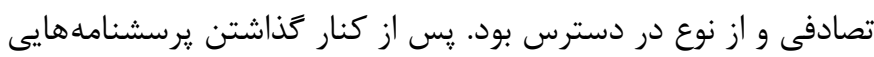

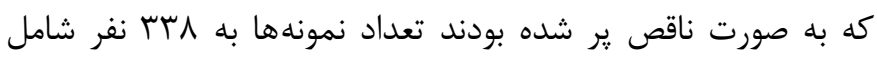

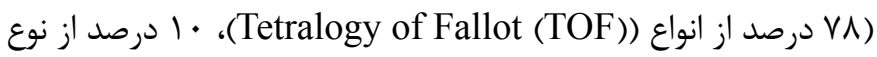
(Transposition of the Great Arteries (TGA)) ديخر سيانوز) رسيد كه شامل 191 يسر و • أl دختر بود. براى همخن ساختن نمونه، فقط كودكان از نوع سيانوز وارد مطالعه شدند. همجنين بهمنظور كنترل عوارض كوتاه مدت عمل جراحى، حداقل يك سال از عملشان كذشته بود، كودكانى كه داراى نقصهاى عصبشناختى هم زمان با بيمارى قلبى مانند سندروم داون بودند يا بيمارى جسمى يا 
بسترى در بيمارستان از يرونده بيماران توسط يزوهشكر استخراج شد

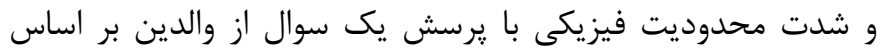
طبقهبندى انجمن قلب نيويورى (New York Heart Association) كه معمولترين نظام طبقهبندى محدوديتهاى فيزيكى در ميان يزشكان است، مشخص شد.

\section{يافته ها}

سن كودكان شركت كننده در اين يزوهش بين 1 تا F| بود. 19 درصد

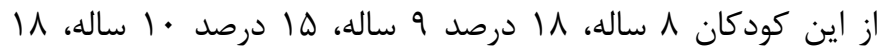

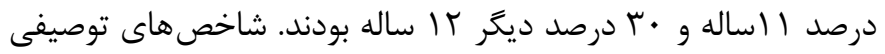
متغيرهاى يزوهش شامل ميانگين، انحراف معيار و همبستخى در جدول

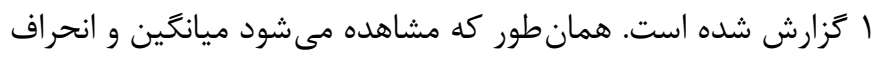

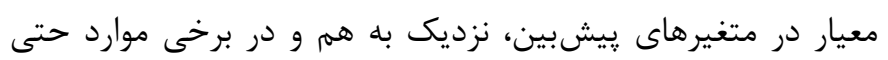

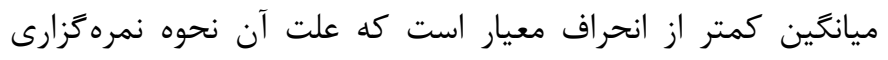

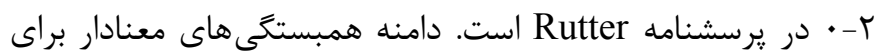
متغيرهاى بيشبين ب// • تا • /|• است. كمترين همبستگى معنادار مربوط به حل مسئله و تعداد دفعات بسترى است و بيشترين همبستكى به درخودفرورفتن و نشخوار نشانهاى افسردىى مربوط است. همجنين دامنه همبستكى هاى معنادار براى متغيرهاى ملاك و متغيرهاى

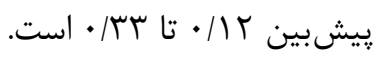

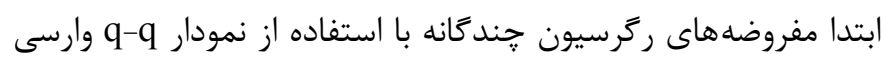

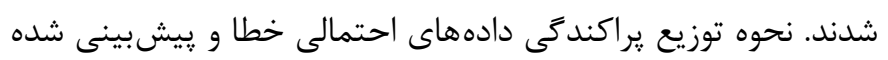

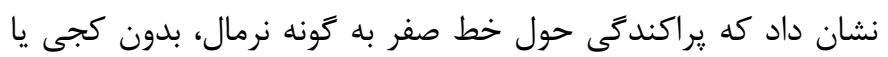
كشيدگى بارز و به صورت متوازن يخش شدهاند. اين نحوه يراكندگى حاكى از نرمال بودن جندمتغيرى دادها، يكسانى واريانس هاى شرطى بهى

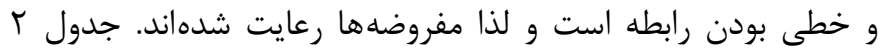
نتايج تحليل ركرسيون خند متغيرى گام به گام و ضرايب استاندارد

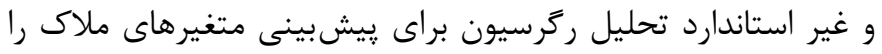
نشان مى دهد.
كه آزمودنى بايد آن را درست كند و ديگرى توسط آزمودنى دستكارى

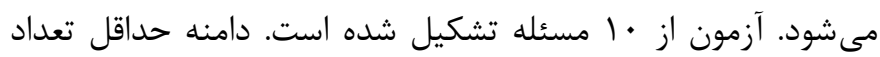

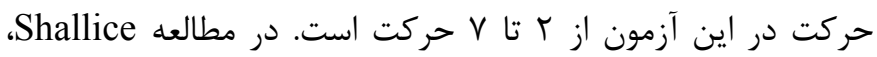

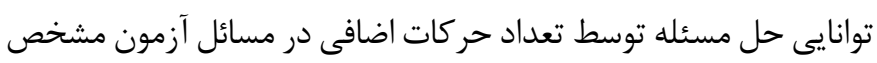
مىشود. يعنى تعداد حركات اضافى، بيشتر از حداقل حركت مول مورد نياز

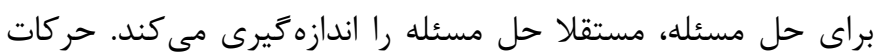

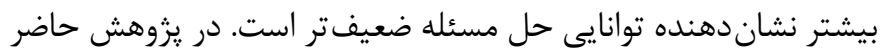
نيز مولفه حل مسئله با اندازءيرى تعداد حركات اضافى مد نظر قرار كرفت. اگرجها روايى زيست محيطى برج لندن توسط برخى يزوهشكَران

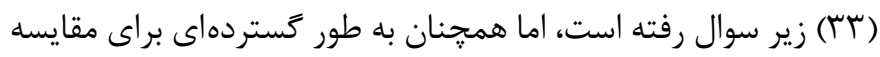

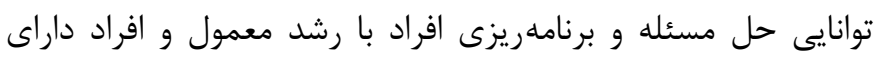
اختلال هاى زنتيكى به كار مىرود (YY)

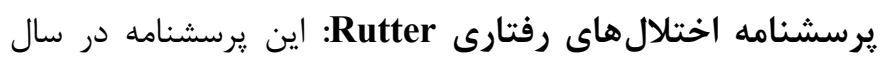

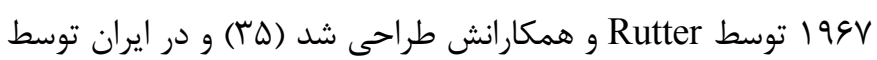

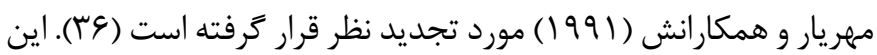
يرسشنامه شامل آسوال است كه FF سوال آن مستقيما از برسشنامه

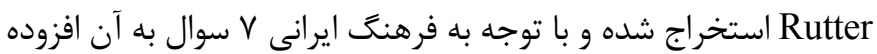
شده است (عَ). هر يك از مواد آزمون در طيف ليكرت سه كزينهاي از

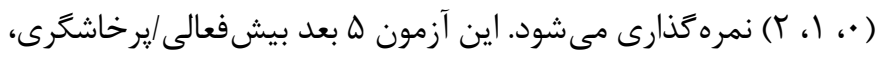

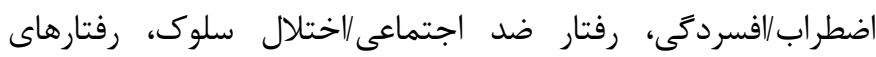

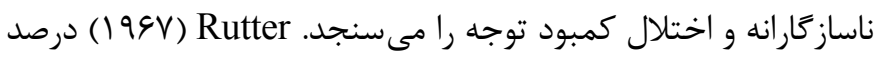

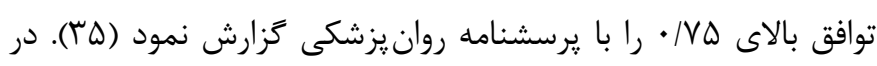

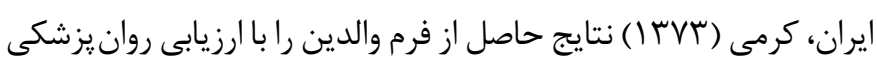

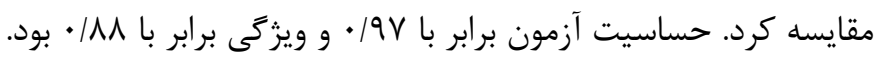

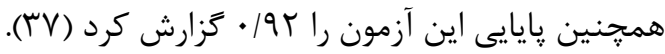
ادراك مادر از شدت بيمارى: از طريق برسش يكى سوال از مادران

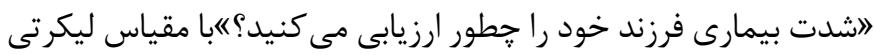
"خفيف، متوسط، شديد" مشخص شد.

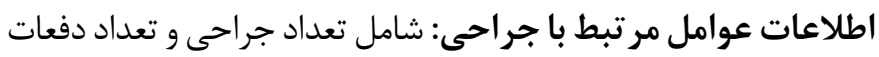

جدول ا. شاخصهاى توصيفى متغيرهاى يزوهش شامل ميانگين، انحراف معيار و ماتريس همبستخى

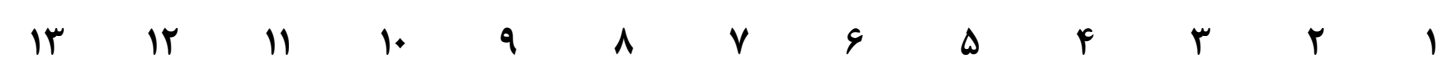

I. إرخاشكرى/VD ADHD

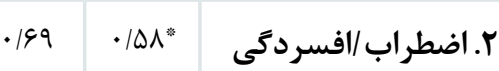

". ناسازگارى اجتماعى | 


\begin{tabular}{|c|c|c|c|c|c|c|c|c|c|c|c|c|c|}
\hline سו & ir & 11 & 1. & 9 & $\Lambda$ & v & $q$ & $\Delta$ & $F$ & r & $r$ & 1 & \\
\hline & & & & & & & & & $\cdot 109$ & $\cdot \mid \Delta \Lambda^{*}$ & $\cdot \mid \Delta Y^{*}$ & $.199^{*}$ & F. رفتار ضد اجتماعى \\
\hline & & & & & & & & $\cdot / r V$ & $\cdot|\Delta|^{*}$ & $\cdot|\Delta|^{*}$ & $\cdot / r V^{*}$ & $\cdot \mid \Delta r^{*}$ & ه. نقص توجه \\
\hline & & & & & & & - &.$/ \cdot r$ & $\cdot / \cdot r$ & $-\cdot / \cdot r$ & $\cdot / \cdot r$ & $\cdot / \cdot r$ & צ. تعداد جراحى \\
\hline & & & & & & - &. $\mid 9 Y^{\circ}$ & $\cdot 1 \cdot \Delta$ & $\cdot / r^{*}$ & .1 .9 & $\cdot 1 \cdot v$ &.$/ 1 r^{\circ}$ & V. دفعات بسترى \\
\hline & & & & & - & $-\cdot \cdot \cdot 1$ & $-\cdot /\left.1\right|^{*}$ & $\cdot / \cdot r$ & $\cdot / \cdot V$ & $\cdot / \cdot \Delta$ & $\cdot 119^{*}$ & $\cdot / \cdot 1$ & ^. محدوديت فيزيكى \\
\hline & & & & - & $-\cdot|\pi|^{*}$ & $\cdot 1$. & $\cdot / 14^{* *}$ & $\cdot / \cdot \wedge$ & $\cdot / \cdot 1$ & .1 .9 & $\cdot|r|^{*}$ & $\cdot / \cdot 1$ & ه. ادراك مادر از شدت \\
\hline & & & $\cdot / 1 \Lambda$ & $\cdot / \cdot r$ & $-\cdot / \cdot \cdot V$ & $\cdot / 1 Y^{*}$ & $\cdot 1 \cdot 9$ & $\cdot / \mu \cdot *$ & $\cdot / r \Lambda^{*}$ & $\cdot / r r^{*}$ & $\cdot / \mu r^{*}$ & $\cdot \pi r^{*}$ & • •ا. افسردَى \\
\hline & & $\cdot / V F$ & $\cdot 19 \cdot *$ & $\cdot 1 \cdot 9$ & $-\cdot / \cdot r$ & $\cdot / \cdot r$ & $.1 \cdot 9$ & $\cdot / r r^{*}$ & $\cdot 119^{*}$ & $\cdot / \cdot V$ & $\cdot \pi \cdot *$ & $\cdot / 1 \Lambda^{*}$ & اו. تعمق \\
\hline & $\cdot / V^{c}$ & $\cdot|\Delta|^{*}$ & $\cdot 1 \mathrm{~A} \cdot *$ & .11 & $-\cdot \cdot \cdot f$ & $\cdot 1 \cdot 1$ & $\cdot 1 \cdot \mathrm{f}^{\mathrm{c}}$ & $\cdot / T \Delta^{*}$ & $\cdot / r r^{*}$ & $\cdot /\left.1\right|^{* *}$ & $\cdot / T \Lambda^{*}$ & $\cdot|r| *$ & זו. درخودفرورفتن \\
\hline- & $\cdot 1 \cdot \Delta$ & $\cdot / \cdot r$ & $\cdot / \cdot \Lambda$ & $-\cdot / \cdot \cdot V$ & $\cdot / \cdot f$ & $\cdot / / r^{*}$ & $\cdot / \cdot r$ & .11 & $\cdot / 1 \Lambda^{*}$ & $\cdot 119^{*}$ & .1 .9 & $\cdot 119^{*}$ & سا. حل مسئله \\
\hline $11 / \wedge 9$ & $1 / \mu F$ & $1 / \cdot \Delta$ & $1 / \cdot 9$ & $r / \cdot 1$ & $r / q$. & $r / 4 q$ & $1 / 90$ & $\cdot / \pi q$ & r & 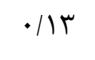 & $\cdot|r|$ & . KT & ميانگين \\
\hline $1 \cdot 194$ & $\cdot / V T$ & $\cdot|V|$ & $\cdot 19 \mathrm{~V}$ & $\cdot|\Delta|$ & $\cdot \mid \Delta V$ & T/FF & $V T / \cdot$ & $\cdot / \pi \Delta$ & $\cdot / r V$ & $\cdot / 14$ & r & 每 & انحراف معيار \\
\hline
\end{tabular}

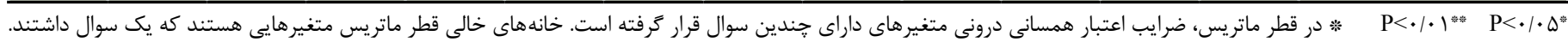

جدول r. نتايج تحليل ركرسيون گام به گام، ضرايب استاندارد و غير استاندارد تحليل ركرسيون براى بيشبينى پيامدهاى روانشناختى كودكان CHD

\begin{tabular}{|c|c|c|c|c|c|c|c|c|c|c|}
\hline $\mathbf{P}$ & $\mathbf{t}$ & $\boldsymbol{\beta}$ & SE & B & $\mathbf{P}$ & $\mathbf{F}$ & $\mathbf{R}$ & \multicolumn{2}{|c|}{ مدل } & متغير ملاك \\
\hline$<\cdot / \cdot \cdot 1$ & $\varphi|\Delta \varphi|$ & 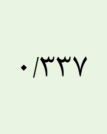 &.$/ \cdot T V$ & $\cdot / 1 \Lambda$ & $<\cdot / \cdot \cdot 1$ & rth &.$/ 11 F$ & نشخوار نشانه هاى & 1 & \multirow{3}{*}{ هرخاشَرى بيش - } \\
\hline$<\cdot / \cdot \cdot 1$ & $q / \Gamma \Delta q$ & • & $\cdot 1 \cdot T V$ &.$/ I V F$ & \multirow[t]{2}{*}{$<\cdot / \cdot \cdot 1$} & \multirow[t]{2}{*}{$r \Delta / r \cdot \Lambda$} & \multirow[t]{2}{*}{. } & نشخوار نشانه افسردى & \multirow[t]{2}{*}{$r$} & \\
\hline$<\cdot / \cdot 1 \cdot$ & r/QVq & (ITr & $.1 \cdot r$ & $\cdot / \cdot r$ & & & & حل مسئله & & \\
\hline$<\cdot / \cdots 1$ & $9 / T \mid \Lambda$ & •|MTI & $\cdot 1 \cdot 11$ & .1111 & $<\cdot / \cdot \bullet 1$ & rN/\&V. & $\cdot / 1 \cdot r$ & نشخوار نشانه افسرد & 1 & \multirow{6}{*}{ اضطراب/افسردگى } \\
\hline$<\cdot / \cdot \cdot 1$ & G/TKG & $\cdot / \pi / \Delta$ & $.1 \cdot 1 \mathrm{~V}$ & $\cdot 11 \cdot 9$ & \multirow[t]{2}{*}{$<\cdot / \cdot \cdot 1$} & \multirow[t]{2}{*}{ TN/KGN } & \multirow[t]{2}{*}{.$/ 14 \Delta$} & نشخوار نشانههاى & \multirow[t]{2}{*}{$r$} & \\
\hline$<\cdot / \cdot \cdot 1$ & $r / \cdot r \Lambda$ & $\cdot / r \cdot f$ & $\cdot / \cdot r \cdot$ & $\cdot / \cdot \lambda r$ & & & & ادراك مادر & & \\
\hline$<\cdot / \cdot \cdot 1$ & q/rq. & $\cdot / \pi / \Delta$ & $.1 \cdot 1 \mathrm{~V}$ & $\cdot 11 \cdot 9$ & \multirow{3}{*}{$<\cdot / \cdot \cdot 1$} & \multirow{3}{*}{$r / / 9 \Delta \Delta$} & \multirow{3}{*}{.$/ 14 \Delta$} & نشخوار نشانه هاى & \multirow{3}{*}{$r$} & \\
\hline$<\cdot / \cdot r$ & $r|\cdot F|$ &.$/ 19$ & $\cdot|\cdot r|$ & .1 .94 & & & & ادراك مادر & & \\
\hline$<\cdot / \cdot \wedge$ & $-r / \zeta \Lambda$. & $-\cdot|| f \mid$ &.$|\cdot r|$ & $-\cdot / \cdot \Delta V$ & & & & محدوديت فيزيكى & & \\
\hline
\end{tabular}




\begin{tabular}{|c|c|c|c|c|c|c|c|c|c|c|}
\hline $\mathbf{P}$ & $\mathbf{t}$ & $\beta$ & $\mathbf{S E}$ & B & $\mathbf{P}$ & $\mathbf{F}$ & $\mathbf{R}$ & \multicolumn{2}{|c|}{ مدل } & متغير ملاك \\
\hline$<\cdot / \cdot \cdot 1$ & 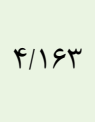 & $\cdot|r T|$ & $\cdot / \cdot Y F$ & $\cdot 11 \cdot 1$ & $<\cdot / \cdot \cdot 1$ & IV/RT & .1 .49 & نشخوار نشانه هاى & 1 & \multirow{3}{*}{ ناسازگًارى اجتماعى } \\
\hline$<\cdot 1 \cdot \cdot 1$ & r/q4. & $\cdot / r \cdot \Lambda$ & $\cdot / \cdot Y F$ & $.1 \cdot 9 \Delta$ & \multirow[t]{2}{*}{$<\cdot / \cdot \bullet 1$} & \multirow[t]{2}{*}{$\mid r / 9 \Lambda \Lambda$} & \multirow[t]{2}{*}{$\cdot / \cdot v \cdot$} & افشردودى مادر نشانه هاى & \multirow[t]{2}{*}{$r$} & \\
\hline$<\cdot 1 \cdot \cdot 9$ & T/VVQ &.$/ 1 \mathrm{FV}$ & $\cdot 1 \cdot \cdot 1$ & 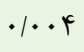 & & & & حل مسئله & & \\
\hline$<\cdot 1 \cdot \cdot 1$ & $\Delta / \Gamma \cdot V$ & $\cdot / T V A$ & . $/ \cdot r t$ & .1110 & $<\cdot 1 \cdot \cdot 1$ & $r V / 199$ & $\cdot 1 \cdot V V$ & نشخوار نشانه هاى & 1 & \multirow{3}{*}{ رفتار ضد اجتماعى } \\
\hline$<\cdot 1 \cdot \cdot 1$ & $\Delta / \cdot \sqrt{ } \varphi$ & . MGY &.$/ \cdot r t$ & $\cdot 11 \cdot 9$ & \multirow[t]{2}{*}{$<\cdot / \cdot \bullet 1$} & \multirow[t]{2}{*}{$19 / \pi / 1$} & \multirow[t]{2}{*}{$\cdot / 1 \cdot r$} & افشردوار نشانه هاى مادر & \multirow[t]{2}{*}{$r$} & \\
\hline$<\cdot / \cdot r r$ & r/ITG & . /19 & $\cdot 1 \cdot \cdot 1$ & 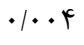 & & & & حل مسئله & & \\
\hline$<\cdot / \cdot \cdot 1$ & $\Delta / V F \mid$ & $\cdot / 499$ & $\cdot / \cdot Y V$ & $\cdot / 1 \Delta \varphi$ & $<\cdot / \cdot \cdot 1$ & $r T / 9 \Delta r$ & $\cdot 1 \cdot 19$ & نشخوار نشانه هاى & 1 & نقص توجه \\
\hline$<\cdot / \cdot 1 T$ & r/DYq & . /Irv & - /TGY & $.199 \mathrm{~V}$ & $<\cdot / \cdot 1$ & 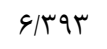 &.$/ \cdot r \cdot$ & دفعات بسترى & 1 & حل مسئله \\
\hline
\end{tabular}

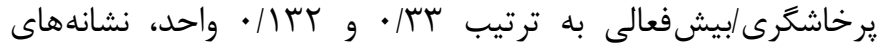

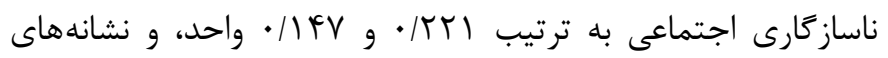

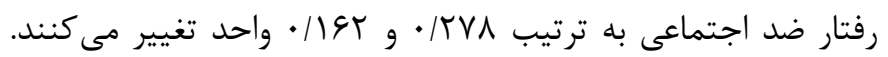
بر اين اساس، مىتوان كفت افسردگى مادر و حل مسئله كودك در

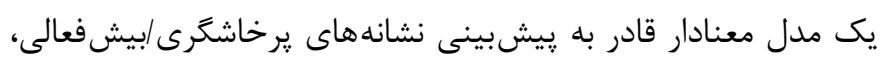
ناساز Fارى اجتماعى، و رفتار ضد اجتماعى در كودك هستند. همجنين، به ازاى يك واحد تغيير در افسردگى مادر، ادراك مادر از شدت بيمارى، و محدوديت فيزيكى؛ نشانههاى اضطراب/افسردگى در كودى به ترتيب

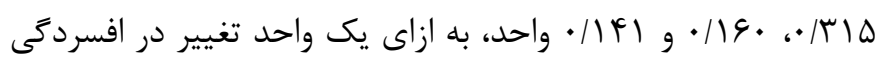

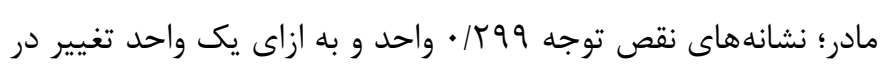

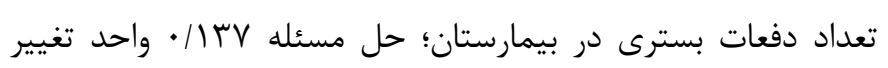

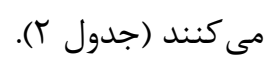

بحث

يزوهش حاضر با هدف شناسايى زيامدهاى روانشناختى عوامل زيستى روانى در كودكان مبتلا به بيمارى قلبى مادرزادى انجام شد. از

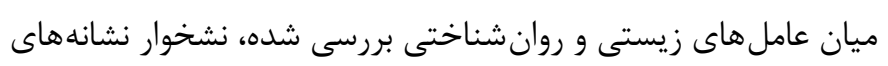

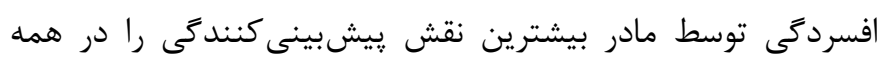
ييامدهاى رفتارى كودكان به دست داد كه اين يافته با يزوهش هاى بينى

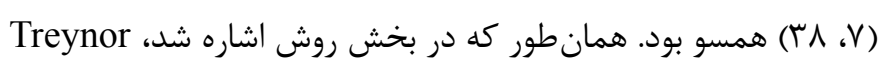

همانطور كه جدول r مشاهده مىشود تحليل رگرسيون براى متغير ملاكى يرخاشكرى /بيشفعالى، ناسازكارى اجتماعى و رفتار ضداجتماعى در دو ₹ام صورت گرفته است و نتايج تحليل رگرسيون در مدل r نشان مى دهد كه نشخوار نشانهاى افسردگى در مادر و حل مسئله كودى، توانايى ييشبينى سا درصد از واريانس نمرات يرخاشگرى /بيشفعالى،

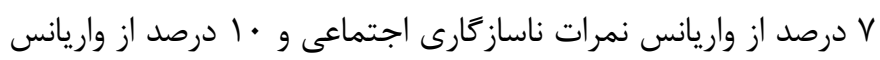
نمرات رفتار ضد اجتماعى را به طور معنادار دارند ( ( • P<). نشخوار

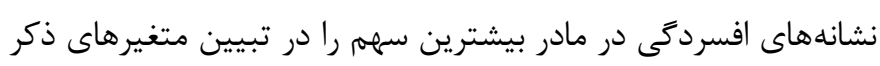
شده داشت. به همين ترتيب، تحليل ركرسيون براى متغير ملاك اضطراب|

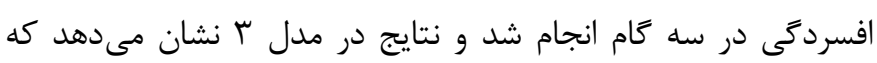
نشخوار نشانه هاى افسردگى در مادر، ادراك مادر از شدت بيمارى و شدت

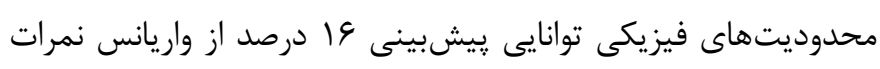

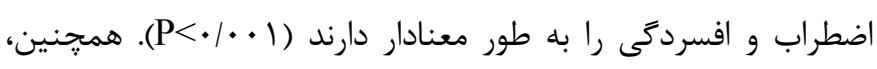
تحليل رگرسيون براى نقص توجه و حل مسئله در يك گام صورت گرفته است و نتايج تحليل ركرسيون نشان مىدهد كه نشانههاى افسردگى در مادر، توانايى ييشبينى ^ درصد از واريانس نمرات نقص توجه

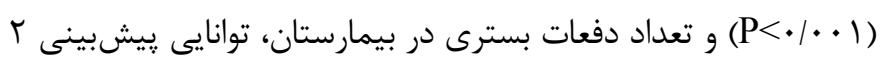
درصد از واريانس نمرات حل مسئله را دارند (1 ( P< (P). با توجه به معنادارى ضرايب م بر اساس يافته ها مى توان بيان كرد كه به

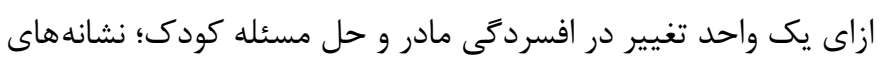


(191V)، ارزيابى افراد از موقعيتهاست كه باعث فراخوانى پاسخ استرس مى گردد (1)). بنابراين ارزيابى والدين از بيمارى فرزندشان به عنوان يك استرسور، در تجربه سطح استرس بسيار تاثير خذار است و همجنين مى تواند در ايجاد محدوديتها براى فرزندشان و نيز بر دران

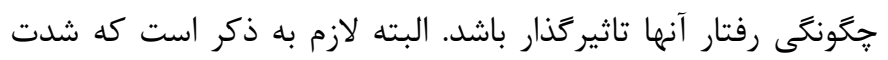

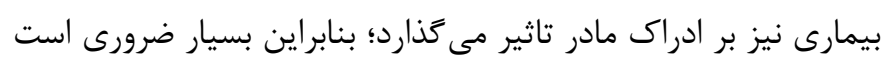

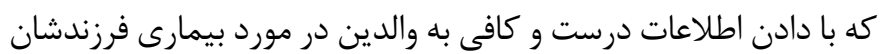
و نيز جَّونكى مراقبت جسمى و روانشناختى از آنها، ادراك درستى از بيمارى كودكشان به دست بياورند و از بيش برآورد بيمارى و كم برآورد كردن توانايى هاى فرزندشان جلو گيرى كنند. از ميان عوامل مرتبط با جراحى شدت محدوديت فيزيكى صرفا بعد اضطراب/افسردىى كودكان را پيشبينى مى كرد. اين يافته با يزوهش

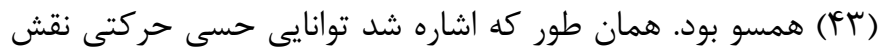

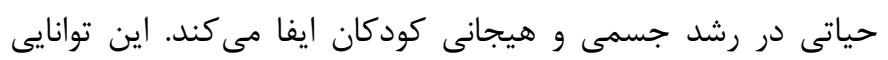
در دوران كودكى و سن مدرسه مىتواند باعث برقرارى ارتباط بهتر،

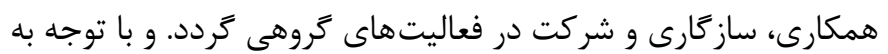
اهميت ارتباط با همسالان، نقش قابل توجهى در ثبات هيجانى و ايجاد تصوير مثبت از خود در كودى ايفا مى كند (T)). هر نوع محدوديت فيزيكى در مراحل حساس رشد مىتواند به اين توانايى آسيب بزند و در نهايت منجر به احساس ناشايستگى و ناتوانى در برقرارى ارتباط موثر با همسالان گردد كه در ايجاد اضطراب و افسردگى نقش دارد.

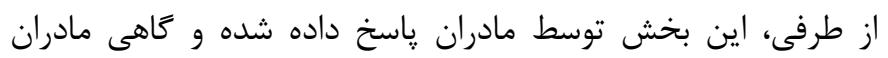

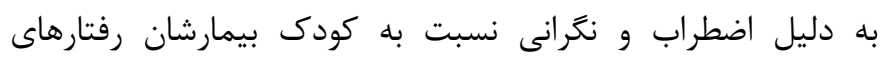

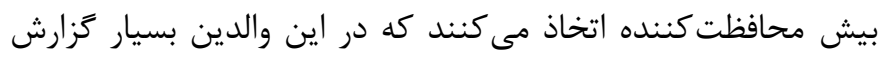

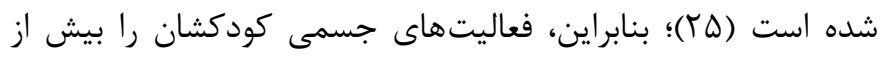
اندازه محدود مى كنند. تاثير مشاهده شده مىتواند تاثير غير مستقيم مادران بيش محافظت كننده مضطرب نيز باشد كه ادراكشان تحت تاثير اضطراب، سو يرانه عمل مى كند.

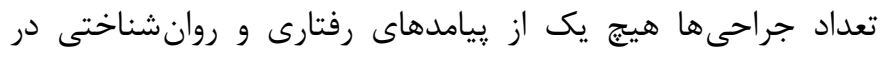

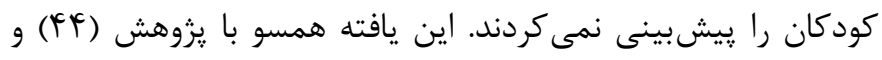

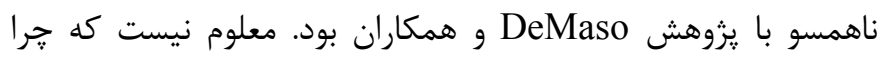
ارتباط بين اين متغيرها در يزوهش هاى مختلف متناقض است. اما آنجه

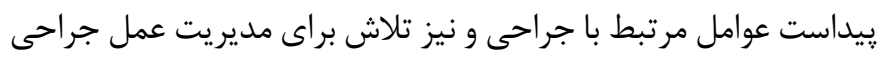

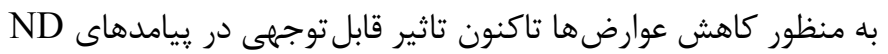
نداشته و بيش از آن، اثرات مرتبط با ويزگكىهاى ذاتى كمتر قابل اصلاح (نوع و شدت CHD، نارس بودن، وزن كمتر هنحام تولد، نزاد

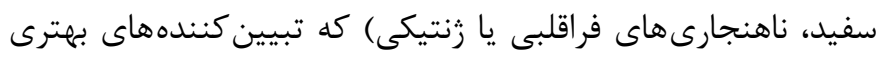

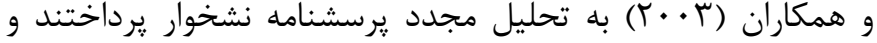
سوالاتى كه با يرسشنامه هاى افسردگى هميوشانى داشته را از دو نوع ديكر نشخوار يعنى تعمق (سازكارانه) و درخود فرورفتكى (ناساز كارانه)

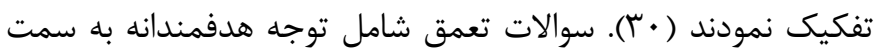

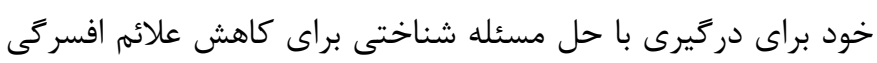
فرد است و در مقابل سوالات عامل در خود فرورفتتى مقايسه منفعلانه

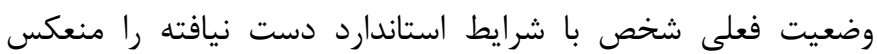
مى كنند؛ در يزوهش حاضر بخش هم يوش با نشانهاى افسردىى نيز استفاده شد كه بيشترين تاثير در پيامدها را نشان داد. اگرجه بر اساس يافته هاى موجود در يزوهشها (•r) نشخوار فكرى به طور كلى مى تواند آغازگر، پِيشبينى كننده يا تشديدكننده و تداوم بخش افسردگى باشد

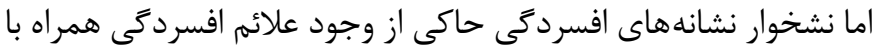

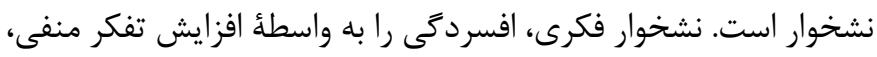

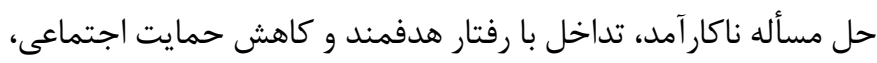

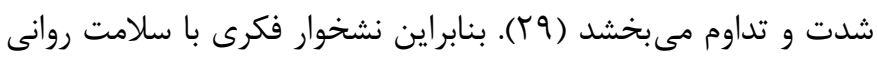
مادر ارتباط منفى دارد. DeJong و همكاران (19 (Y) اظهار كردند كه نشخوار فكرى مى تواند به دليل كنترل شناختى منفى و سوگيرى شناختى بر קَّونكَى پاسخ گَويى و حساسيت مادر نسبت به نوزاد تاثير

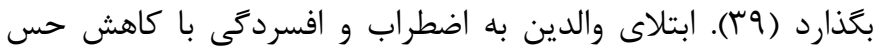
مسئوليت يذيرى نسبت به مراقبت، آموزش، و تغذيه فرزند خود همراه

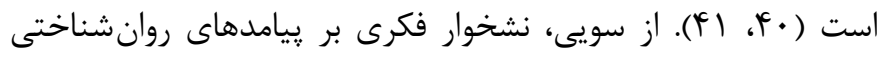

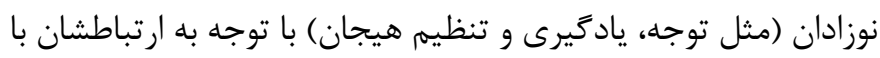
ياسخ گو بودن و حساسيت مادر، تاثير مى كذارد (وج). بنابر اين، احتمال

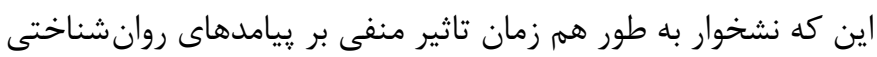
بحذارد و آنها را در مسير رشد منفى قرار دهد وجود دارد. مادران اين لهان كودكان به نوعى سو گوار يك فرزند سالم هستند و در صورت به كار گيرى سبك ياسخ نشخوارى نسبت به مشكلات، كه يك روش منفعلانه و خود ارزيابانه به خلق يايين است (•r)، مىتواند اثرات منفى بر بيامدهاى روان شناختى كودكان داشته باشد. به نظر مىرسد آموزش راهكارهاى

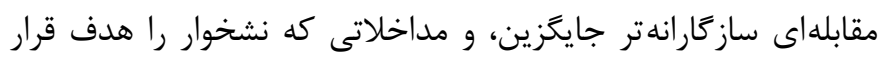

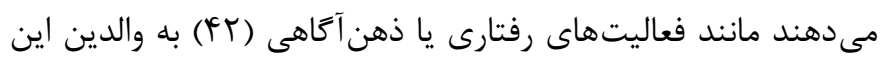

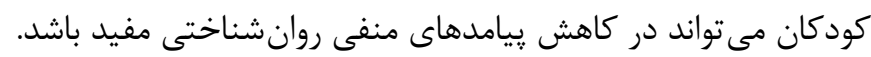

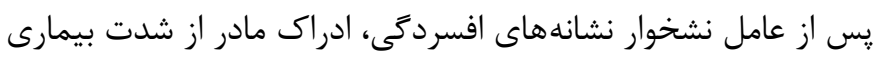
بيشترين نقش را در اضطراب/افسركى كودى ايفا كرد. همانَّونه كه مشاهده شد ادراك مادر از شدت بيمارى بيش از عوامل مرتبط با جراحى در پيامدهاى روانشناختى كودكان تاثيركذار است. اين يافته با يزوهش (V) همسو است. بر اساس نظريه استرس Lazarus و همكارانش 
توانايى كمى در احساس كردن و استفاده موثر از وضعيت هيجانى و روانى ديكران ماند شناسايى تمايلات ديكران و درك ديدكاه ديكران

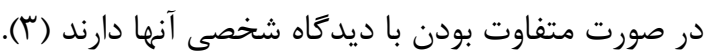
در اين يزوهش به علت محدوديتهاى مالى و زمانى، ارزيابى مشكلات

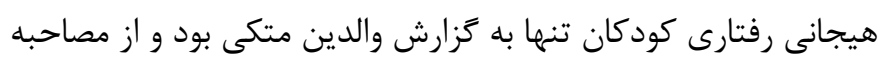

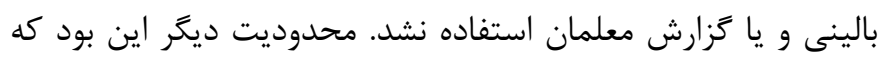

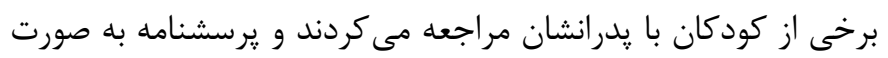

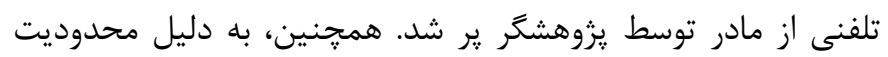
در تعداد نمونههاى مراجعه كننده و نيز محدوديت زمانى، با اين كه با

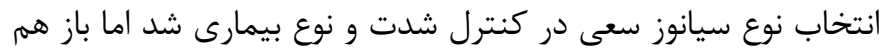
طيف سيانوز بسيار كسترده است به طور مثال حتى بيمارى نوع TOF نيز شدتهاى گَوناكونى را در بر مى گيرد؛ بنابراين، يِيشنهاد مى شود در يزوهشهاى بعدى از انواع همكن ترى استفاده كردد. همجنين بِيشنهاد

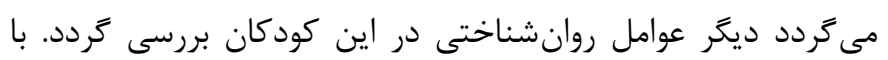

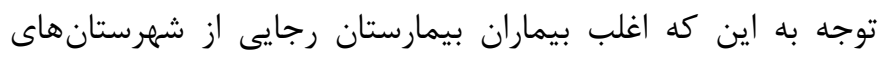

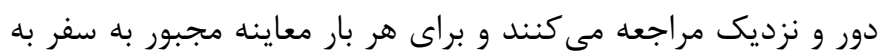
يايتخت هستند، اين امر ممكن است آسيبهايى به عملكرد تحصيلى اين كودكان وارد كند. از اين رو، ييشنهاد مى گردد راهكارهايى براى بهبود امكانات يزشكى در شهرستانها و ارتباط با بيمارستانهاى يُشرفته تر در نظر كرفته شود. همجنين، استفاده از مشاورههاى آنلاين يزشكى در صورت امكان مىتواند ضرورت سفر را از بين ببرد و تعداد

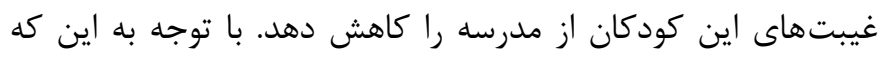

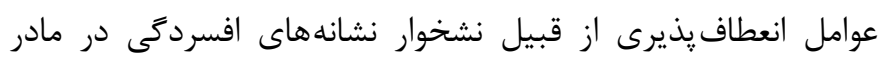

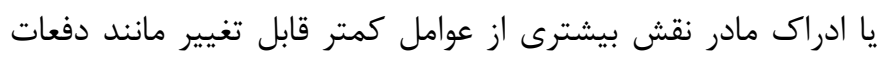
بسترى يا تعداد جراحىها در ييامدهاى روانشناختى اين كودكان ايفا مى كنند، بنابراين فراهم آوردن حمايتهاى روانى اجتماعى و مداخلات روانشناختى به ويزه براى مادران كه مراقبان اصلى هستند بسيار اهميت دارد. همجنين با توجه به نقش ير رنگ نشخوار فكرى مادر در

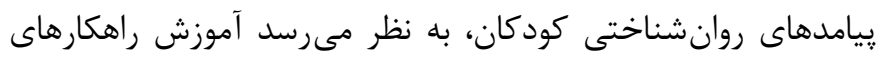

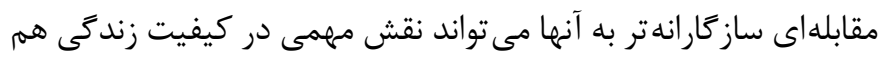

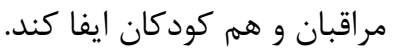

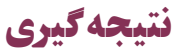

به طور كلى، نتايج يزوهش تاكيد بر سهم عوامل روانشناختى به ويزه

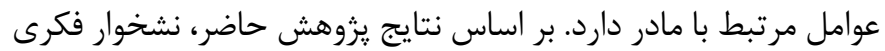

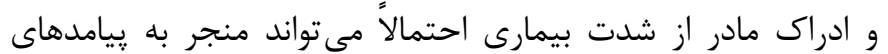
رفتارى در كودكان CHD شود. اين عوامل نسبت به عوامل مرتبط
از هييوكسى و آسيبهاى مغزى هستند و عوامل محيطى اقتصادى

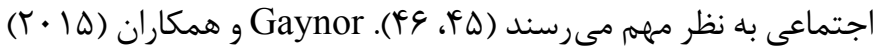

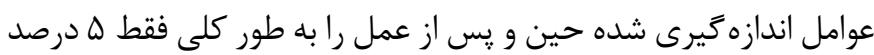
در קييامدهاى رشدى حركتى و روانى سهيم دانستند (ه\&).

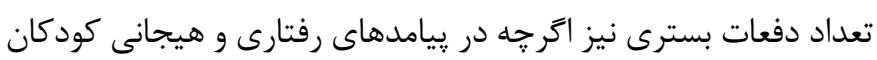

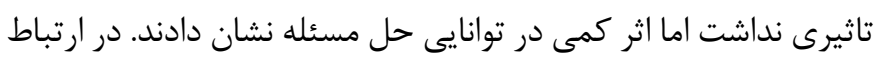

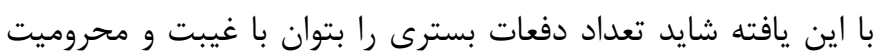
بيشتر از كلاسهاى مدرسه مرتبط دانست كه اين مسئله مى تواند تا

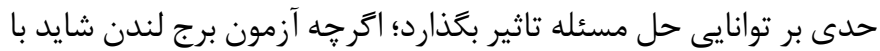

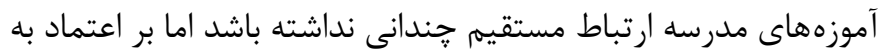
نفس كودك در حل مسائل بى تاثير نيست. همجنين بر اساس تحقيقات

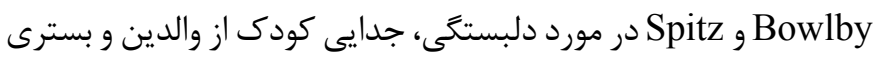

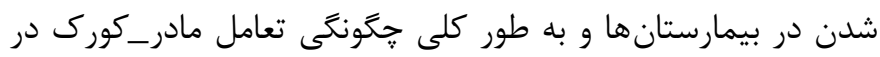

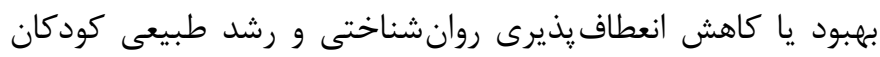

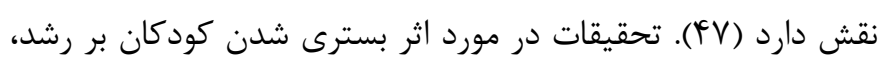

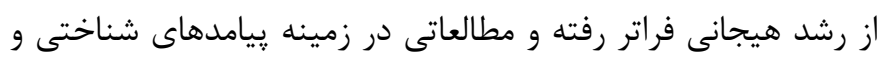

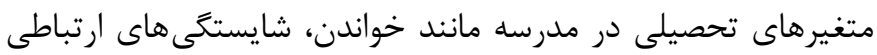

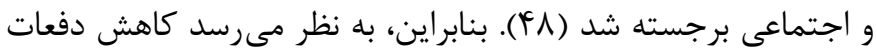

بسترى به شيوههاى كوناكون توسط كادر سلامت ضرورى است.

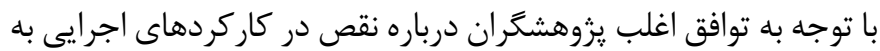

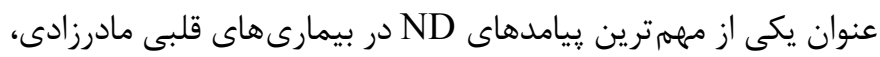

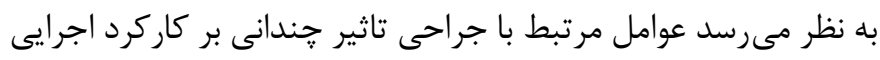

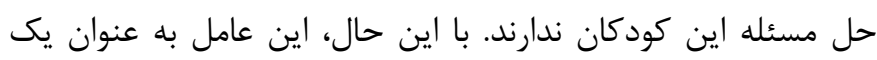

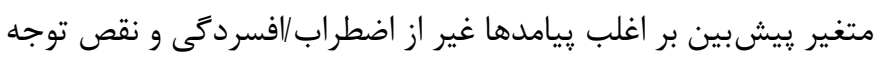
نقش داشت. بر اساس يافتههاى به دست آمده، حل مسئله در ابعاد

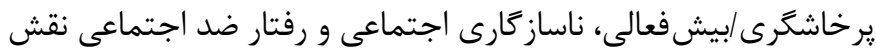

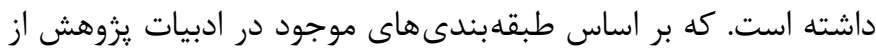

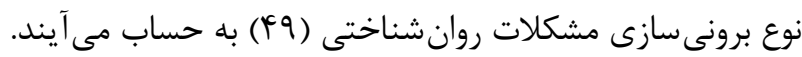

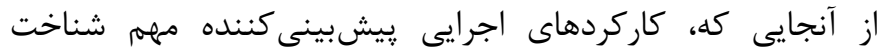

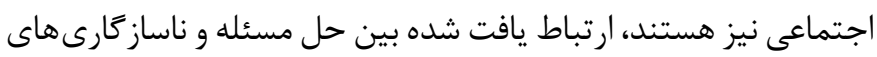

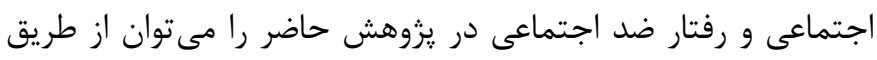

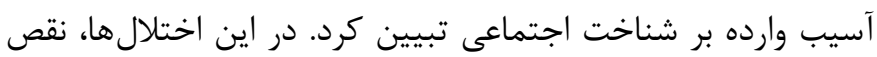

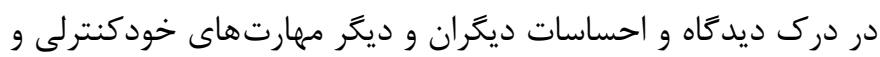
كنترل تكانه مشاهده مى شود (••). نقص در شناخت اجتماعى شامل دران آسيب در تئورى ذهن و درك هيجانات يِجيده، نيز بخشى از فنوتيب

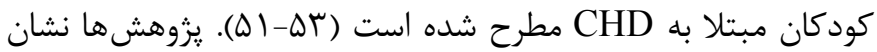
دادهاند كودكان و نوجوانان d-TGA، تترالوزى فالوت و قلب تك بطنى، 


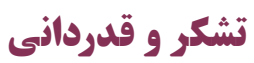

از صندوق حمايت از يزوهشگران معاونت علمى فناورى رياست

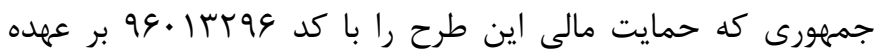
كرفتند، همجنين تمامى :رستاران بخش اكو بيمارستان قلب رجايى كه در جمع آورى دادهها يزوهشگران را يارى كردند به ويزه سركار خانم شهين كاكاوند و كودكان و والدينى كه در اين :يزوهش همكارى كردند كمال تشكر و قدردانى به عمل مى آيد.

\section{References}

1. Bertoletti J, Marx GC, Junior H, Pedro S, Pellanda LC. Quality of life and congenital heart disease in children and adolescents. Brazilian Cardiology Archives. 2014;102(2):192-198.

2. Marino BS, Lipkin PH, Newburger JW, Peacock G, Gerdes M, Gaynor JW, Mussatto KA, et al. Neurodevelopmental outcomes in children with congenital heart disease: Evaluation and management: A scientific statement from the American Heart Association. Circulation. 2012;126(9):1143-1172.

3. McCusker C, Casey F. Congenital heart disease and neurodevelopment: Understanding and improving outcomes. Cambridge:Academic Press;2016.

4. Karsdorp PA, Everaerd W, Kindt M, Mulder BJ. Psychological and cognitive functioning in children and adolescents with congenital heart disease: A meta-analysis. Journal of Pediatric Psychology. 2006;32(5):527-541.

5. McCusker CG. Recovery-V-emergence of neurodevelopmental deficits in congenital heart disease from infancy to 7 years. In Paper presented at the 2nd Annual Cardiac Neurodevelopmental Symposium; 2013 June 6; Cincinnati, USA;2013.

6. Muller J, Berner A, Ewert P, Hager A. Reduced health-related quality of life in older patients with congenital heart disease: A cross sectional study in 2360 patients. International Journal of Cardiology. 2014;175(2):358-362.

7. DeMaso DR, Campis LK, Wypij D, Bertram S, Lipshitz M, Freed M. The impact of maternal perceptions and medical severity on the adjustment of children with congenital heart disease. Journal of Pediatric Psychology. 1991;16(2):137-149.
با جراحى نقش مهمترى در ييامدهاى روانشناختى كودكان ايفا مى كنند. همجنين نقص در متغير شناختى حل مسئله در كودكان مىتواند منجر به ييامدهاى روانشناختى از نوع برونىسازى CHD كردد. با توجه به يافتههاى به دست آمده از يزوهش، مطلوب است كه متخصصين سلامت و مراقبان بهداشتى مؤلفه هاى روانشناختى مادر و كودى را در كار بالينى با اين بيماران و خانوادههايشان مورد توجه

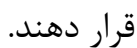

8. Ernst MM, Marino BS, Cassedy A, Piazza-Waggoner C, Franklin RC, Brown K, et al. Biopsychosocial predictors of quality of life outcomes in pediatric congenital heart disease. Pediatric Cardiology. 2018;39(1):79-88.

9. Fonseca A, Nazare B, Canavarro MC. Parental psychological distress and quality of life after a prenatal or postnatal diagnosis of congenital anomaly: A controlled comparison study with parents of healthy infants. Disability and Health Journal. 2012;5(2):67-74

10. Sarrechia I, De Wolf D, Miatton M, Francois K, Gewillig M, Meyns B, et al. Neurodevelopment and behavior after transcatheter versus surgical closure of secundum type atrial septal defect. The Journal of Pediatrics. 2015;166(1):31-38.

11. Schmidt D, Seehagen S, Vocks S, Schneider S, Teismann T. Predictive importance of antenatal depressive rumination and worrying for maternal-Foetal attachment and maternal well-being. Cognitive Therapy and Research. 2016;40(4):565-576.

12. Joormann J. Differential effects of rumination and dysphoria on the inhibition of irrelevant emotional material: Evidence from a negative priming task. Cognitive Therapy and Research. 2006;30(2):149-160.

13. Wells A. Metacognitive therapy for anxiety and depression. New York:Guilford press;2011.

14. Mor N, Daches S. Ruminative thinking: Lessons learned from cognitive training. Clinical Psychological Science. 2015;3(4):574-592.

15. Miyake A, Friedman NP, Emerson MJ, Witzki AH, Howert- 
er A, Wager TD. The unity and diversity of executive functions and their contributions to complex "frontal lobe" tasks: A latent variable analysis. Cognitive Psychology. 2000;41(1):49-100. 16. Tester-Jones M, O’Mahen H, Watkins E, Karl A. The impact of maternal characteristics, infant temperament and contextual factors on maternal responsiveness to infant. Infant Behavior and Development. 2015;40:1-11.

17. Torowicz D, Irving SY, Hanlon AL, Sumpter DF, Medoff-Cooper B. Infant temperament and parent stress in 3-month-old infants following surgery for complex congenital heart disease. Journal of Developmental and Behavioral Pediatrics: JDBP. 2010;31(3):202-208.

18. Ogden J. Health psychology: A textbook. 5th ed. New York:McGraw-Hill Education;2012.

19. Silva AM, Vaz C, Areias ME, Vieira D, Proenca C, Viana V, et al. Quality of life of patients with congenital heart diseases. Cardiol Young. 2011;21(6):670-676.

20. Bellinger DC, Wypij D, Rappaport LA, Jonas RA, Wernovsky G, Newburger JW. Neurodevelopmental status at eight years in children with dextro-transposition of the great arteries: the Boston Circulatory Arrest Trial. The Journal of Thoracic and Cardiovascular Surgery. 2003;126(5):1385-1396.

21. Garson SL. Psychological aspects of heart disease in childhood. In: Garson A, Brickner T, Fisher DJ, Neish SR, editors. The science and practice of pediatric cardiology. 2nd ed. Baltimore:William and Wilkins;1998. pp. 2929-2938.

22. WoolfKing SE, Anger A, Arnold EA, Weiss SJ, Teitel D. Mental health among parents of children with critical congenital heart defects: A systematic review. Journal of the American Heart Association. 2017;6(2):e004862.

23. Berk L. Development through the lifespan. Hoboken, NJ:Pearson Education;2010.

24. Diller GP, Dimopoulos K, Okonko D, Li W, Babu-Narayan SV, Broberg CS, et al. Exercise intolerance in adult congenital heart disease: Comparative severity, correlates, and prognostic implication. Circulation. 2005;112(6):828-835.

25. Bjarnason-Wehrens B, Schmitz S, Dordel S. Motor devel- opment in children with congenital cardiac diseases. European Cardiology. 2008;4(2):92-96.

26. Zelazo PD, Qu L, Müller U, Schneider W, Schumann-Hengsteler R, Sodian B. Hot and cool aspects of executive function: Relations in early development. In Schneider W, Schumann-Hengsteler R, Sodian B, editors. Young children's cognitive development: Interrelationships among executive functioning, working memory, verbal ability, and theory of mind. Mahwah, NJ:Erlbaum;2005. pp. 71-93.

27. Hovels-Gurich HH, Bauer SB, Schnitker R, Willmes-Von Hinckeldey K, Messmer BJ, Seghaye MC, et al. Long-term outcome of speech and language in children after corrective surgery for cyanotic or acyanotic cardiac defects in infancy. European Journal of Paediatric Neurology. 2008;12(5):378-386.

28. Goldstein S, Naglieri JA. Handbook of executive functioning. New York:Springer;2014.

29. Nolen-Hoeksema S, Morrow J. A prospective study of depression and posttraumatic stress symptoms after a natural disaster: The 1989 Loma Prieta Earthquake. Journal of Personality and Social Psychology. 1991;61(1):115-121.

30. Treynor W, Gonzalez R, Nolen-Hoeksema S. Rumination reconsidered: A psychometric analysis. Cognitive Therapy and Research. 2003;27(3):247-259.

31. Mohammadkhani S, Purmand NS, Hassanabadi H. An empirical test of a metacognitive model of rumination and depression in non-clinical population. Modern Psychological Research. 2013;8(30):183-204.

32. Shallice T. Specific impairments of planning. Philosophical transactions of the Royal Society of London. Biological Sciences. 1982;298(1089):199-209.

33. Phillips LH. The role of memory in the Tower of London task. Memory. 1999;7(2):209-231.

34. Azadi B, Seddigh A, Tehrani-Doost M, Alaghband-Rad J, Ashrafi MR. Executive dysfunction in treated phenylketonuric patients. European Child \& Adolescent Psychiatry. 2009;18(6):360-368.

35. Rutter M. A children's behaviour questionnaire for comple- 
tion by teachers: Preliminary findings. Journal of Child Psychology and Psychiatry. 1967;8(1):1-11.

36. Mehryar AH, Yousefi F. Diagnosis and treatment of mental illness in children. Tehran:Roshd;1991. (Persian)

37. Karami S. Comparison behavioral disorder and PTSD in children and adolescents (9-17y) in Zanjan city after 3 year with others place [MSc Thesis]. Tehran:Institiue of Psychiatry, Iran University of Medical Sciences;1994. (Persian)

38. Psychogiou L, Moberly NJ, Parry E, Russell AE, Nath S, Kallitsoglou A. Does fathers' and mothers' rumination predict emotional symptoms in their children?. British Journal of Clinical Psychology. 2017;56(4):431-342.

39. DeJong H, Fox E, Stein A. Rumination and postnatal depression: A systematic review and a cognitive model. Behaviour Research and Therapy. 2016;82:38-49.

40. Minkovitz CS, Strobino D, Scharfstein D, Hou W, Miller T, Mistry KB, et al. Maternal depressive symptoms and children's receipt of health care in the first 3 years of life. Pediatrics. 2005;115(2):306-314.

41. Meleski DD. Families with chronically ill children: A literature review examines approaches to helping them cope. The American Journal of Nursing. 2002;102(5):47-54.

42. Topper M, Emmelkamp PM, Ehring T. Improving prevention of depression and anxiety disorders: Repetitive negative thinking as a promising target. Applied and Preventive Psychology. 2010;14(1-4):57-71.

43. Bjarnason-Wehrens B, Dordel S, Schickendantz S, Sreeram $\mathrm{N}$, Brockmeier K. Exercise training in congenital heart diseases. In: Niebauer J, editor. Cardiac rehabilitation manual. Cham, Switzerland:Springer, Cham;2017. pp. 257-291.

44. Hovels-Gurich HH. Factors influencing neurodevelopment after cardiac surgery during infancy. Frontiers in Pediatrics. 2016;4:137.

45. Gaynor JW, Stopp C, Wypij D, Andropoulos DB, Atallah
J, Atz AM, et al. Neurodevelopmental outcomes after cardiac surgery in infancy. Pediatrics. 2015;135(5):816-825.

46. Newburger JW, Sleeper LA, Bellinger DC, Goldberg CS, Tabbutt S, Lu M, et al. Early developmental outcome in children with hypoplastic left heart syndrome and related anomalies: The single ventricle reconstruction trial. Circulation. 2012;125(17):2081-2091.

47. Spitz RA, Wolf KM. Anaclitic depression: An inquiry into the genesis of psychiatric conditions in early childhood, II. The Psychoanalytic Study of the Child. 1946;2(1):313-342.

48. Quinton D, Rutter M. Early hospital admissions and later disturbances of behaviour: An attempted replication of Douglas' findings. Developmental Medicine \& Child Neurology. 1976;18(4):447-459.

49. Fombonne E. The Child Behaviour Checklist and the Rutter Parental Questionnaire: A comparison between two screening instruments. Psychological Medicine. 1989;19(3):777-785.

50. Carlson SM, Moses LJ. Individual differences in inhibitory control and children's theory of mind. Child Development. 2001;72(4):1032-1053.

51. Bellinger DC, Wypij D, Rivkin MJ, DeMaso DR, Robertson Jr RL, Dunbar-Masterson C, et al. Adolescents with d-transposition of the great arteries corrected with the arterial switch procedure: Neuropsychological assessment and structural brain imaging. Circulation. 2011;124(12):1361-1369.

52. Bellinger DC, Rivkin MJ, DeMaso D, Robertson RL, Stopp C, Dunbar-Masterson C, et al. Adolescents with tetralogy of Fallot: Neuropsychological assessment and structural brain imaging. Cardiology in the Young. 2015;25(2):338-347.

53. Calderon J, Angeard N, Pinabiaux C, Bonnet D, Jambaque I. Facial expression recognition and emotion understanding in children after neonatal openheart surgery for transposition of the great arteries. Developmental Medicine \& Child Neurology. 2014;56(6):564-571. 